\title{
Sheep production on medic and weedy pasture in semi-arid Morocco
}

\author{
J. TIEDEMAN, B. BOULANOUAR, S. CHRISTIANSEN, AND M. DERKAOUI
}

Tiedeman is associate professor, Department of Natural Resource Sciences, Washington State University, Pullman Wash. 99164-6410; Boulanouar and Derkaoui are scientists, Arididoculture Centre, B.P. 589, Settat, Morocco; Christiansen is pasture scientist, ICARDA, P.O. Box 5466 Aleppo, Syria.

\begin{abstract}
Most farms in the semi-arid region of Morocco are mixed cereal-livestock producers. Livestock, dominated by sheep, account for more than one third of farm income but production is far below potential. Low quality cereal straw and weeds from fallow land are the main sources of forage, but provide inadequate nutrition. Fall planted wheat is usually grown in rotation following a year of weedy fallow. The replacement of the weedy fallow by sowing a self regenerating annual Medicago spp., a system known as ley farming in Australia, was tested in Morocco to determine if it could increase livestock production. Ewe and lamb liveweight gain, wool yield, and forage standing crop during grazing were compared between medic and weedy fallow pastures. Large significant differences $(P<0.05)$ in forage standing crop and both lamb and ewe liveweight gain occurred in 1990/91 but no differences occurred the previous 2 years when medic was initially sown nor the following 2 years during severe drought. In 1991 lambs gained $67 \%$ and ewes gained $60 \%$ more liveweight, plus wool yield was $23 \%$ higher on medic as compared to weedy fallow. In addition, $3,000 \mathrm{~kg} \mathrm{ha}^{-1}$ of forage remained after grazing medic as compared to $568 \mathrm{~kg} \mathrm{ha}^{-1}$ after weedy fallow.
\end{abstract}

Key Words: ley-farming, annual Medicago spp., weedy fallow, cereal medic rotation

Weaning rates of lambs in the semi-arid region of central Morocco are low, only 40-65\% (Berger et al. 1989). Almost all land is grazed by livestock but forage production and quality are low, well below potential. The main sources of forage in the semi-arid region are: a) cereal residues including straw and stubble ( 2.8 million ha), b) weedy fallow (1.4 million ha), and c) rangeland (6 million ha) (Watts and El Mourid 1988).

Many farmers in Morocco grow cereal in rolation with weedy fallow. Of the 7.7 million ha of arable land, 2 million ha are left to weedy fallow annually following a cereal crop (World Bank 1979). In a survey conducted in the semi-arid region, $25 \%$ of the arable land was weedy fallow (Derkaoui 1989). Farmers claim that they practice cereal/weedy fallow rotation because they cannot continuously crop cereals, and need the weeds as forage for their livestock. This is done in spite of low forage production from weeds, many of which are not palatable to livestock.

Ley farming is a system where self regenerating annual legumes are grazed in rotation with cereal crops. Sufficient seed

This research was supported in part by USAID through Project no. 608-0136. Manuscript accepted 21 Jun. 1997. reserves of hard seeded legumes are built up in the soil after sowing the first year, so that there is no need to sow the legume again in subsequent years. The technology has been practiced in southern Australia since 1930 (Puckridge and French 1983). The Ministry of Agriculture in Morocco has promoted the ley farming techology directly from Australia before being able to adapt it to local conditions. Since 1985 , over 47,000 have been sown to annual legumes, mostly medic (Medicago spp.) cultivars from Australia (Benyassine 1991).

This experiment was conducted from 1988 to 1993 in a semiarid area of Central Morocco where the cereal/weedy fallow rotation is common. The objective was to compare the sheep production and forage availability from weedy fallow pasture to pasture sown with self regenerating annual medic.

\section{Materials and Methods}

The study was conducted on 12 one-hectare sized pasture plots on sloping land at the Ain N'zagh Agricultural Experiment Station near Settat, Morocco. The soil is a gravelly clay loam, deep Vertisol in the depressions and a shallow Mollisol with an underlying calcarious sandstone of decomposed bedrock below $30 \mathrm{~cm}$ depth on the ridgetops. At the onset of the experiment there were no differences $(P>0.25)$ between treatment plots in soil nitrates and organic matter, with moderate $(5 \mathrm{ppm})$ and high (4\%) levels respectively. Phosphorus $\left(\mathrm{P}_{2} \mathrm{O}_{5}\right)$ levels were high but different $(P=0.05)$ between medic $(16.2 \mathrm{ppm})$ and weedy fallow plots (12.5 ppm). This region of central Morocco is semi-arid with mean annual precipitation of $386 \mathrm{~mm}$ as recorded at Settat based upon 67 years of record (Watts and El Mourid 1988). January is the coldest month with a minimum of $4^{\circ} \mathrm{C}$ whereas August is the hottest with a maximum of $45^{\circ} \mathrm{C}$.

The experimental design was a randomized complete block with 2 treatments and 3 replications. The treatments were medic and weedy fallow pastures, each in rotation with bread wheat Triticum aestivum L. Animal liveweight gain and available forage biomass collected periodically were analyzed using a split plot in time. The experiment was 2-phased where pasture or cereal phases of the experiment were both present in any given year. Each replication included 2 plots of each treatment in either the pasture or wheat phase of the rotation for a total of 4 plots per replication as follows: wheat phase of medic/wheat rotation, wheat phase of weedy fallow/wheat rotation, medic phase of the medic/wheat rotation and the weedy fallow phase of the weedy fallow/wheat rotation. Each plot was 1 ha in size and fenced. The plots that were medic 
or weedy fallow 1 year were sown with wheat the following year to complete the 2-year rotation. During the third and subsequent years the medic and weedy fallow plots were allowed to regenerate spontaneously after the cereal crop.

Medic pastures were established on a seedbed prepared with an offset disk harrow. Medic seed was broadcast in early November 1988 on 3 plots at the rate of $22 \mathrm{~kg} \mathrm{ha}^{-1}$ of a mixture of Australian cultivars that consisted of equal weights of burr medic ( $M$. polymorpha L. cv 'Serena') and barrel medic (M. truncatula Gaertner cv. 'Jemalong'). Plots that were in the wheat phase of the rotation in $1988 / 89$ were sown with medic the following year in November 1989. A cultipacker was used to cover the seed and pack the seedbed. Medic seedlings were counted 1 month after planting by randomly placing 50 quadrats $(20 \times 40 \mathrm{~cm})$ in each plot. Because of low seed reserves during the regeneration years (54 kg ha ${ }^{-1}$ in July 1990 and $40 \mathrm{~kg} \mathrm{ha}^{-1}$ in July 1991), medic plots were resown in November 1990 and October 1991 at the rate of $40 \mathrm{~kg} \mathrm{ha}^{-1}$. The medic sown in 1990 was a mixture composed of $45 \% M$. polymorpha $\mathrm{L}$. cv 'Doukkala' (a local variety), $10 \% M$. polymorpha L. cv 'Serena') and $45 \%$ M. truncatula Gaertner cv. 'Jemalong'. The medic sown in 1991 was $M$. truncatula Gaertner cv. 'Cyprus'. Mcdic seed reserves were measured in July at the soil surface and to a depth of $5 \mathrm{~cm}$ from 20 random $10 \mathrm{~cm}$ diameter soil cores in 1990 and from 20 randomly placed quadrats (20 $\times 40 \mathrm{~cm}$ ) in 1991 . The same procedure was used in 1992 but to a depth of $10 \mathrm{~cm}$. Soil was washed through 1 and $2 \mathrm{~mm}$ sieves to remove seed pods and seeds of medic.

Each fall, 6 plots for the cereal phase of the trial were planted with bread wheat (Triticum aestivum L. cv. 'Saada'). This variety is resistant to the Hessian fly (Mayetiola destructor) which is a common insect of the region. The seedbed was prepared by cultivation with an offset disk harrow. Seed was broadcasted by hand at the rate of $130 \mathrm{~kg} \mathrm{ha}^{-1}$ then covered with an offset disk harrow. During the first 2 years an application of $20 \mathrm{~kg} \mathrm{ha}^{-1}$ of $\mathrm{N}$ as ammonium sulfate (21-0-0) was broadcasted at planting of the cereal but not the medic or weedy fallow, and a top dressing of $20 \mathrm{~kg} \mathrm{ha}^{-1}$ of $\mathrm{N}$ as ammonium nitrate $(33-0-0)$ was applied to the cereal 1 month after seeding.

Growing lambs of the Sardi and Timahdit breeds were statified by weight, and equal numbers of each breed randomly assigned to each of the 6 pasture plots. The 1-hectare pasture plots were stocked using "put and take management" with a maximum of 13 growing male lambs (15 kg, 2-3 months of age) during the first 2 growing seasons of $1988 / 89$ and $1989 / 90$. The pasture plots were stocked with a fixed stocking rate of 6 ewes $(33 \mathrm{~kg})$ and their lambs ( $8 \mathrm{~kg}, 4-8$ weeks of age) during the 1990/91 and 1991/92 growing seasons, and 6 male lambs $(23 \mathrm{~kg})$ during the 1992/93 growing season. Ewes with lambs were used because lambs were too young to be weaned (2-6 weeks of age) when the pastures were ready for grazing (1990-92) and ewes are more aggressive at grazing the less palutable weeds than lambs. Sheep were routinely drenched against internal parasites and vaccinated for enterotoxemia.

Grazing began after fall rains brought on the medic and weeds. After wheat harvest, the sheep were moved to stubble pasture. The date of each grazing period is listed in Table 1. Lambs and ewes were weighed weekly after an overnight shrink. Total liveweight gain, expressed in $\mathrm{kg} \mathrm{ha}^{-1}$ was calculated as the sum of liveweight gain of either lambs or ewes that grazed the pasture plots. Wool was clipped and weighed at the end of the grazing season.
Table 1. Lamb liveweight gain (kg/ha) on medic as compared to weedy fallow.

\begin{tabular}{|c|c|c|}
\hline Year & Medic & Weedy Fallow \\
\hline & $(\mathrm{kg} \mathrm{ha-1})$ & $\left(\mathrm{kg} \mathrm{ha}^{-1}\right)$ \\
\hline $\begin{array}{l}\text { 1988/89 Spring pasture } \\
1 \text { Feb. } 89-15 \text { Jun. } 89\end{array}$ & $269 a$ & $279 a^{1}$ \\
\hline $\begin{array}{l}\text { 1989/90 Spring pasture } \\
21 \text { Dec. } 89-1 \text { Jun. } 90\end{array}$ & $178 \mathfrak{a}$ & 191a \\
\hline $\begin{array}{l}\text { 1990/91 Spring pasture } \\
19 \text { Dec. } 90-7 \text { May } 91\end{array}$ & $164 a$ & $98 \mathrm{~b}$ \\
\hline $\begin{array}{l}\text { Summer pasture } \\
7 \text { May } 91-16 \text { Jul. } 91\end{array}$ & $-24 a$ & $13 b$ \\
\hline $\begin{array}{l}\text { 1991/92 Spring pasture } \\
\text { 18 Feb. } 92-26 \text { May } 92\end{array}$ & $84 a$ & $86 a$ \\
\hline $\begin{array}{l}\text { 1992/93 Spring pasture } \\
13 \text { Apr. } 93-20 \text { Jun. } 93\end{array}$ & $50 a$ & $43 a$ \\
\hline
\end{tabular}
0.05 level.

Botanical components of aboveground biomass (medic, other legumes, diotyledonous weeds, and grasses) were measured at intervals of 3-6 weeks during each grazing season. Forage standing crop was clipped to ground level from 20 randomly placed quadrats $20 \times 40 \mathrm{~cm}$ ) that were combined to form 1 composite sample for each plot. These samples were separated into botanical components the same day clipped, then oven dried at $60^{\circ} \mathrm{C}$ for 48 hours beforc being weighed.

In 1991, the quantity of forage in the pasture was low because of late rains. Thus from 30 January to 9 April the sheep grazed a common reserve pasture in the morning, the medic or weedy fallow pastures in the afternoon and ewes were supplemented with $300 \mathrm{~g} \mathrm{day}^{-1}$ of barley grain and straw ad lib. Sheep were moved to a reserve pasture when the biomass of the pasture dropped below $300 \mathrm{~kg} \mathrm{ha}^{-1}$. Lambs were weaned on 7 May 1991 when ewes were removed from the pastures. Lambs continued grazing the pastures until moved onto stubble.

The drought during 1992/93 was so severe that grazing did not begin until April and wheat was not sown for the cereal phase. Since wheat was not sown, lambs were moved to these pastures to utilize the regenerating medic and weeds after fully utilizing the forage from the medic and weedy fallow phase.

\section{Results}

\section{Precipitation}

Precipitation was below average throughout the study (Fig. 1) but far below average the 2 drought years of 1991/92 and $1992 / 93$. There were early rains in $1991 / 92$ but then very little until mid-February. In 1992/93 there was very little rain until after March, much dryer than the previous year and the driest year on record.

\section{Medic Establishment and Seed Reserves}

In medic plots, medic density was $263 \pm 8$ seedlings $\mathrm{m}^{-2}$ in the first establishment year and $384 \pm 86$ seedlings $\mathrm{m}^{-2}$ in the second establishment year. The density was low compared to 400 plants $\mathrm{m}^{-2}$ as recommended in Australia by Carter (1982) and very low compared to the values of 1,000-2,000 established seedlings $\mathrm{m}^{-2}$ as recommended by Puckridge and French (1983) necessary to 


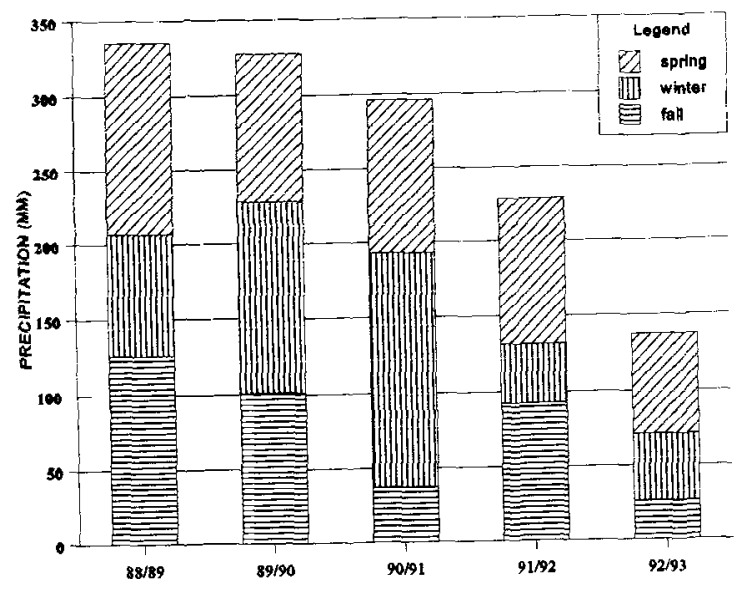

Fig. 1. Precipitation (mm) as recorded in Settat during 1988-1993.

allow the medic to compete against weeds. Medic seed reserves on medic pastures in July prior to the grazing season were 54,40 , and $135 \mathrm{~kg} \mathrm{ha}^{-1}$ for the years 1990,1991 , and 1992 respectively; well below the $200 \mathrm{~kg} \mathrm{ha}^{-1}$ recommended by Carter (1982).

\section{Animal Production}

Each year lamb liveweight increased on both treatments reaching a plateau near the end of the grazing season (Fig. 2). Large significant increases in both lamb and ewe weight occurred in $1991(\mathrm{P}<0.05)$ (Table 2) but no differences in lamb gain were detected in the previous 2 medic establishment years, nor the last 2 drought years (Table 1). The year 1990/91 was the first year medic regenerated from seed reserves (built up in the soil from the previous rotation), and where medic was well established after supplemental seed was sown in the fall. Ewes with lambs were also used as the grazing animal rather than weaned lambs. In 1991 lambs gained $67 \%$ more and ewes gained $60 \%$ more liveweight $(\mathrm{P}<0.05)$ on the medic than on the weedy fallow pastures (Table 2). There was also more than twice as much forage remaining after the grazing in the medic pastures as compared to the weedy fallow pastures $(P<0.05)$. Lambs on the medic pasture produced more wool $\left(7.6 \mathrm{~kg} \mathrm{ha}^{-1}\right)$ than on the weedy fallow pasture $\left(6.2 \mathrm{~kg} \mathrm{ha}^{-1}\right)(\mathrm{P}<0.05)$.

After weaning, lambs lost weight on the medic treatment but not on the weedy fallow pasture in 1991. However the lambs on the medic remained significantly heavier than those on the weedy fallow.

\section{Forage Production}

There were no differences in forage availability between treatments during any year except 1990/91 when grazed medic pastures maintained more than double the forage biomass throughout

Table 2. Liveweight gain in 1991 of ewes and lambs, lamb wool yield and residual forage on medic as compared to weedy fallow $(P<0.05)$.

\begin{tabular}{lcc}
\hline \hline & Medic & Weedy Fallow \\
\hline Ewes $\left(\mathrm{kg} \mathrm{ha}^{-1}\right)$ & 80 & 50 \\
Lambs $\left(\mathrm{kg} \mathrm{ha}^{-1}\right)$ & 164 & 98 \\
Wool $\left(\mathrm{kg} \mathrm{ha}^{-1}\right)$ & 7.6 & 6.2 \\
Residual forage $\left(\mathrm{kg} \mathrm{ha}^{-1}\right)$ & 3000 & 568 \\
\hline
\end{tabular}

Table 3. Forage standing crop (kg/ha) and legume composition of grazed medic and weedy fallow (W.F.) pastures 1988-93.

\begin{tabular}{lccccc}
\hline \hline Season & \multicolumn{2}{c}{ Forage } & & \multicolumn{2}{c}{ Legume\% } \\
\cline { 2 - 3 } \cline { 5 - 6 } & Medic & W.F. & & Medic & W.F. \\
\hline 13 Jan. 89-27 Apr. 89 & 2407 & 2313 & & 24 & 23 \\
9 Jan. 90-24 Apr. 90 & 1171 & 1597 & & 39 & $1^{*}$ \\
21 Jan. 91-25 Jul. 91 & 1706 & $593^{*}$ & & 36 & $\left.1^{*}\right) \ldots$ \\
5 Feb. 92-20 May 92 & 551 & 620 & & 21 & 13 \\
7 Apr. 93-16 Jun. 93 & 362 & 388 & & 27 & $13^{*}$ \\
\hline *Significant at the 0.05 level.
\end{tabular}

the year (Table 3 ). This was the only year a difference in liveweight gain was observed where medic pastures produced more than the weedy fallow. The year, 1990/91 was of favorable precipitation compared to the severe drought years of 1991-93 (Fig. 1).

Lcgume biomass was a major component of the vegetation on medic plots but a minor component on weedy fallow plots every year except the first (Table 3). During the 1989/90 season the percent composition of medic in the total biomass of the grazed medic plots ranged from a high of $44 \%$ in early spring to a low of $21 \%$ in May by the end of the season. A similar legume composition was measured during the 1990/91 season with a high of $48 \%$ in early spring to a low of $30 \%$ by the end of May. Less than $1 \%$ legume biomass was measured in weedy fallow in 1989/90 and 1990/91. In late April 1991 the composition of medic was $34 \%$ in grazed medic plots compared to $1.5 \%$ in grazed weedy fallow plots. Legume composition on medic pastures was maintained at about double that of the weedy fallow during the drought years of 1991-93.

\section{Discussion}

Since a fixed stocking rate was used after $1989 / 90$, the greater amount of residual forage on the medic pastures in 1990/91 could not be converted to animal gain. An increase in stocking rate should increase the liveweight produced per hectare on the medic, but seed reserves that are currently below recommended levels would be further reduced. After weaning, lambs should be sold or be placed on fattening rations since they may lose weight if pastured without supplements during summer. The increased forage availability is most likely the reason for the higher livestock gains on the medic in 1990/91. In only 1 year out of 5, livestock gain was higher on medic than weedy fallow, the same and only year that forage availability was the highest on medic. Improved forage quality as reflected in the high legume composition of the medic pasture could also contribute to animal gain. However no differences were detected the other 4 years even though legume composition was highest on the medic pastures. It appears that medic is not better than weedy fallow during severe drought years.

One can only speculate as to the reasons weight gain and forage biomass differences were detected the third year but not the previous 2 years where precipitation patterns were low but near normal. There are 2 possibilities. Ewes with lambs were used in 1990/91 and may have been more efficient users of medic forage than weaned lambs used the first 2 years. Another reason may have been that medic was not sufficiently established until the 
1988-89

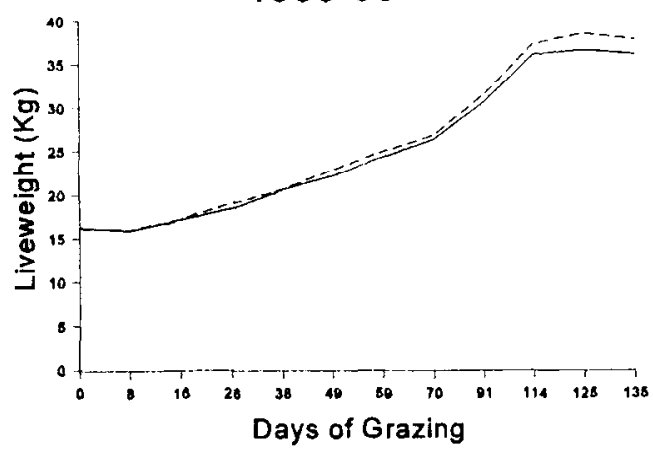

1990-91

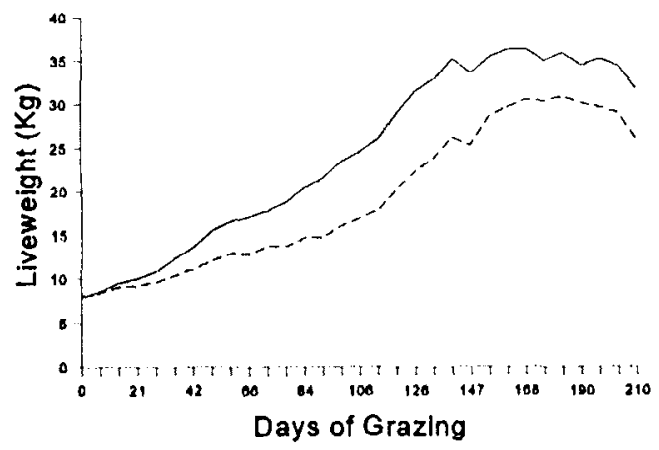

1992-93

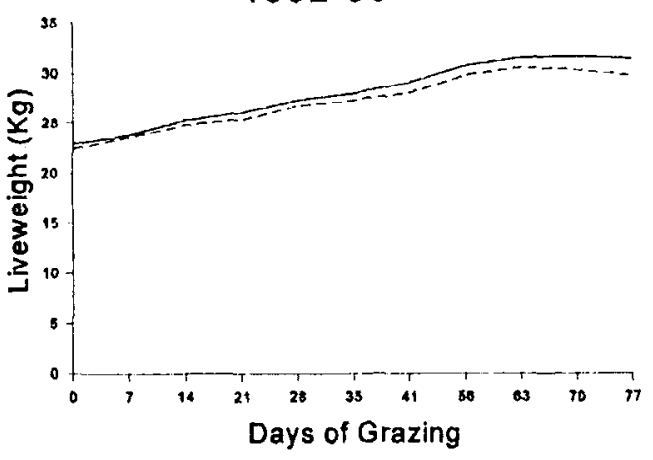

1989-90

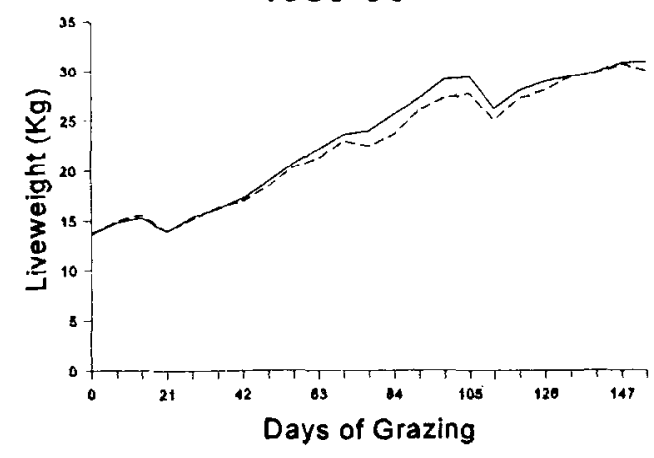

$1991-92$

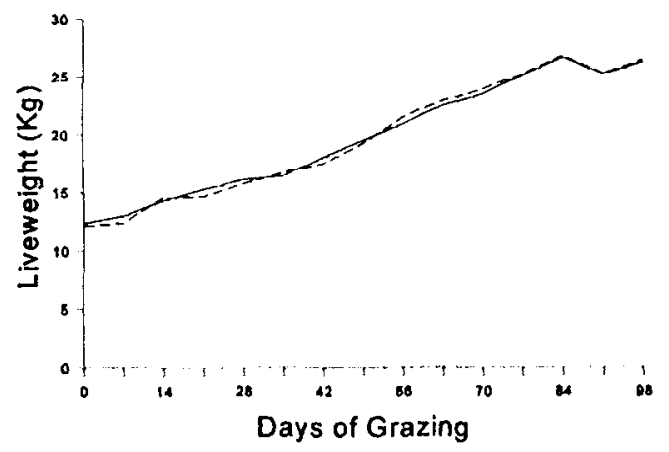

Medic

Weedy Fallow

Fig. 2. Lamb liveweight at weekly intervals during the grazing seasons $1988-93$.

third year, the year the stand developed from residual seed in the soil plus supplemental seed sown in the fall of 1990 . Ewes with lambs should be used as the grazing animals for research and adequate seed reserves should be maintained in the soil.

After a good year of production in 1990/91 the seed reserve in the upper $5 \mathrm{~cm}$ of the soil surface was $135 \mathrm{~kg} \mathrm{ha}^{-1}$ which is still below the level of $200 \mathrm{~kg} \mathrm{ha}^{-1}$ as recommended by Carter (1982) to produce at least 400 plants per $\mathrm{m}^{-2}$ for successful establishment. However the seed at the soil surface from current years production exceeded the $20 \mathrm{~kg} \mathrm{ha}^{-1}$ needed per year to replenish the seed reserve (Tow 1989). It appears that the establishment of a satisfactory seed reserve in the soil is one of the major constraints to the system. Cocks (1992) suggested a minimum of 150 $\mathrm{kg} \mathrm{ha}^{-1}$ of seed reserves to produce 1,000 seedlings $\mathrm{m}^{-2}$ as a compromise between summer grazing needs and long-term persistence of medic in pasture. It was observed that many farmers in our area grow cereal 2 continuous years before weedy fallow. This practice would further reduce the medic seed reserves in the soil. The problem of low seed reserves is not unique in Morocco. In Australia, Carter and Lake (1985) found only 4 fields out of 35 where seed reserves approached $400 \mathrm{~kg} \mathrm{ha}^{-1}$ and plant densities approached $1,000 \mathrm{~m}^{-2}$. Under local grazing and cultivation practices, it is doubtful that medic seed reserves would be maintained at these recommended levels.

Some farmers plow deep which is thought to reduce the success of medic during the fallow phase. This theory has not been tested. 
Deep plowing will bury seed deeper than $10 \mathrm{~cm}$ which has been shown to prevent emergence. Derkaoui (1986) demonstrated that the best seeding depth $(1984 / 85)$ was at $3-4 \mathrm{~cm}$ but no major reduction in emergence occurred at the maximum depth of $10 \mathrm{~cm}$. Once the seed reserves are built up in the soil profile, deep plowing will bury surface seed pods but at the same time bring to the surface some of the seeds buried in previous years. In 1990/91 we observed a high rate of medic germination after fall rains $(75 \mathrm{~mm})$ wet the soil surface. Most of the germination was from the current year's seed crop that remained on or near the wet soil surface. Most of these plants died during the following months of drought. If these fields had been deep plowed before the rains, some of those seeds would have been buried below the level of moisture penetration and would not have germinated until adequate moisture was available. In addition burial protects medic seed from fluctuating temperatures which reduce hardseed breakdown. In Australia buried seed remained hard longer than seeds not buried (Taylor and Ewing 1988). Further research needs to be conducted to evaluate the effect of deep plowing on medic establishment.

Medic varieties or other legumes that have a high level of hard seeds may be better suited to conditions in Morocco than soft seed varieties. Varieties that have small seed are more likely to escape damage when sheep consume pods and may pass through the animal and remain viable. Carter $(1980,1981)$ found that only $2 \%$ of the seed that was consumed remained viable but that small seed varieties passed through with less damage than large seeds, and small pods with fewer seeds escaped grazing longer than larger pods. Varieties such as those of snail medic [Medicago scutellata (L.) Miller] have large seeds more likely to be damaged in digestion. Snail medic also has less hard seed than most other varieties so much would germinate and be lost during the cereal phase. Ilard seed varieties with small seeds such as the local burr medic are more appropriate than snail medic for the semi-arid region. Other legume species should be considered. Astragalus boeticus L. is a highly palatable legume present in all of our pastures. Many seeds of this plant passed through the digestive tract undamaged as evident in a dense stand that germinated from the manure in the outside holding pens. Local medic and other legume species with small hard seeds that remain viable after passing through the digestive system of sheep need to be identified and developed.

Melilotus sulcata Desf. is another legume that persists in our pastures and is abundant in the weedy fallow throughout the region. A similar species Melilotus afficinalis (L) lam. was used as a green manure crop in rotation with wheat in the Palouse region of Washington state before commercial fertilizers became readily available to farmers.

Proper grazing management is needed to assure the success of the medic rotation. Moderate grazing levels early are needed to control weeds especially the grasses that begin growth earlier than medic. Only light grazing should occur during the flowering and seed pod development stage. Grazing should be stopped before all current year's seed pods are consumed. Once the reserves are well established, at lcast $40 \mathrm{~kg} \mathrm{ha}^{-1}$ of current year's seed production should remain to replenish the seeds that germinated or were destroyed during the previous 2 years of the rotation.

This research has demonstrated that once medic is well established and precipitation is favorable, substantial increases in forage biomass and livestock production can be achieved where weedy fallow is replaced with medic. This response occurred in only 1 out of 5 years. No differences were demonstrated during 2 years of establishment or during 2 years of drought.

\section{Literature Cited}

Berger, Y.M., A. Kabbali, and G.E. Bradford. 1989. Sheep production and management in a Mediterranean climate. Small Ruminant Collaborative Research Support Program, Institut Agronomique et Veterinaire Hassan II Morocco and Univ. of California, Davis, Calif.

Benyassine, A. 1991. Characteristics of farming enterprises and adaptation of the ley farming system. (In French) p. 9-27. In: Amine, Maria (Ed) Ley Farming, Proc. Séminaire National, Rabat, Morocco, Direction de la Production Végétale, Ministère de l'Agriculture et de la Rèforme Agraire, Actes Editions, Rabat, Morocco.

Carter, E.D. 1980. The survival of medic seeds following ingestion of intact pods by sheep. p. 178. In: Proc. Austral. Agron. Conf., Lawes, Qld. Australia.

Carter, E.D. 1981. Seed and seedling dynamics of annual medic pastures in South Australia. p. 447-450. In: Proc. XIV Int. Grassl. Congr. Lexington, Ken.

Carter, E.D. 1982. The need for change in making the best use of medics in the cereal-livestock farming systems of South Australia. Proc. Aust. Agron. Conf. Wagga Wagga, NSW, Aust.

Carter, E.D. and Lake. 1985. Seed, seedling and species dynamics of grazed annual pastures in South Australia. In: Proceedings of the XV Internat. Grassl. Congr.

Cocks, P.S. 1992. Plant attributes leading to persistence in grazed annual medics (Medicago spp.) growing in rotation with wheat. Aust. J. Agr. Res. 43:1559-70.

Derkaoui, M. 1986. Effect of seeding depth on plant vigor in annual medics. Annual Rep. Aridoculture Center, INRA/MIAC, Ministère de l'Agriculture et de la Réforme Agraire, Settat, Morocco.

Derkaoui, M. 1989. Plant-animal associations in the cereal semi-arid zones of Morocco. p. 1311-1312. In: Proceedings XVI Internat. Grassl. Congr., Assoc. Française pour la Production Fourragère, Nice, France. Institue National de La Researche Agronomique, Route de Saint-Cyr, 78026 Versailles, Cédex, France.

Puckridge, D.W. and R.J. Freach. 1983. The annual legume pasture in cereal-ley farming systems of Southern Australia: a review. Agr., Ecosystems and Environ. 9:229-242.

Taylor, G.B. and M.A Ewing. 1988. Effect of depth of burial on the longevity of hard seeds of subterranean clover and annual medics. Aust. J. Exp. Agr. 28:77-81.

Tow, P.G. 1989. Monitoring annual Medicago ley pastures for management decisions. p. 601-602. In: Proceedings XVI International Grassland Congress, Association Française pour la Production Fourragère, Nice, France. Institue National de La Researche Agronomique, Route de Saint-Cyr, 78026 Versailles, Cédex, France.

Watts, D. and M. El Mourid. 1988. Rainfall patterns and probabilities in the semi-arid cereal production region of Morocco. Institute National de La Researche Agronomique, Settat Morocco.

World Bank. 1979. Morocco: Economic and social development report. World Bank, Wash. D.C. 